\section{Screening Short-day Onion Cultivars for Resistance to Fusarium Basal Rot}

\author{
Jessica A. Gutierrez ${ }^{1}$ and Christopher S. Cramer ${ }^{2}$ \\ Department of Agronomy and Horticulture, Box 30003, MSC 3Q, New Mexico \\ State University, Las Cruces, NM 88003-0003
}

\begin{abstract}
Additional index words. Allium cepa, disease incidence, disease progression, field disease screening, Fusarium oxysporum f. sp. cepae
\end{abstract}

\begin{abstract}
Fusarium basal rot (FBR), caused by Fusarium oxysporum Schlechtend.:Fr. f. sp. cepae (H.N. Hans.) W.C. Snyder \& H.N. Hans, is a soilborne fungal disease that affects bulb onions (Allium cepa L.) worldwide. Short-day onion cultivars that are resistant to FBR are lacking. The goal of this project was to screen fall-sown onion germplasm for FBR resistance using a mature bulb field screening at harvest and after 4 weeks in storage. The project was conducted for 2 years, and in each year, 26 fall-sown onion lines were grown in a field known to produce a high incidence of fusarium-basal-rot-infected bulbs. When all the bulbs in a plot were mature, the basal plates of 20 bulbs were cut transversely and each plate was rated for disease severity on a scale of one (no diseased tissue) to nine $(\mathbf{7 0 \%}$ or more diseased). Bulbs were stored and rerated at 2 and 4 weeks after harvest. Disease severity and incidence were higher in the first year than in the second year. Both severity and incidence increased as bulbs were stored for 4 weeks. NMSU 00-25 exhibited the lowest disease severity and incidence in both years at harvest time and after storage. 'Buffalo' and 'Cardinal' exhibited the highest severities and incidences across both years and at harvest time and after storage. Other entries exhibited high or low disease severity and incidence but not consistently across years and between harvest time and after storage. In the development of FBR resistant cultivars, breeding lines should be evaluated over multiple years and bulbs should be stored for 4 weeks before being screened.
\end{abstract}

Fusarium basal rot (FBR), caused by Fusarium oxysporum Schlechtend.:Fr. f. sp. cepae (H.N. Hans.) W.C. Snyder \& H.N. Hans (FOC), is a soilborne disease affecting onions (Allium cepa L.) worldwide, and has caused significant economic losses in Italy, Japan, South Africa and the United States (Sumner, 1995). Onions grown on soils naturally infested with FOC have shown a $23 \%$ field and storage loss (Bacher et al., 1989). In New Mexico, FBR is the second most important soilborne disease affecting onions (N. Goldberg, personal communication, 1998). Variety trials at New Mexico State Univ. have resulted in a FBR mean severity and incidence of 2.2 and $38.2 \%$, respectively, in the 2001 season (Cramer et al., 2002). Similar trials in the following year resulted in severity and incidence means of 2.2 and $26.4 \%$, respectively (Cramer and Muyhi, 2002). The fungus attacks seedlings, causing pre- and postemergence damping-off, root rot of older plants and stem plate discoloration and basal rot of bulbs in the field and in storage (Abawi and Lorbeer, 1972). Infection by FOC can occur through wounding or by direct penetration by the fungus through the basal stem plate, but symptoms can also be seen in the leaves, roots and bulb scales (Sumner,

Received for publication 6 Nov. 2003. Accepted for publication 19 May 2004. This research was funded in part by the Minority Biomedical Research Support-Research Initiative for Scientific Enhancement Program (GM 61222-02), the N.M. Agricultural Experiment Station, and the N.M. Dry Onion Commission.

${ }^{1}$ Former graduate research assistant.

${ }^{2}$ Associate professor of horticulture and corresponding author.

1995). Temperatures ranging from 25 to 28 ${ }^{\circ} \mathrm{C}$ are optimum for disease development (Sumner, 1995).
Losses from infection by FOC can be reduced by rotation with nonsusceptible crops in infested fields (Sumner, 1995) or by soil fumigation, which has been effective but not economical (Bacher et al., 1989). The best control measure is the use of resistant onion cultivars (Sumner, 1995). Short-day onion cultivars that are resistant to FBR are lacking. Mature bulbs of short-day onion cultivars have been screened for resistance to FBR with very few exhibiting resistance (Marlatt, 1958; Stadnik and Dhingra, 1996). The goal of this project was to screen short-day onion germplasm for FBR resistance using mature bulb field screening. In addition, disease progression over time of bulbs harvested from the field was also observed to determine if bulbs exhibited true resistance in the field or if symptoms were delayed.

\section{Materials and Methods}

In total, 26 fall-seeded, onion cultivars were sown in fields known to produce a high incidence of FBR-infected bulbs at the Fabian Garcia Research Center in Las Cruces, N.M. (Cramer et al., 2001). In the past 3 years, FBR susceptible cultivars have expressed a disease incidence at harvest of $64 \%$ to $99 \%$ when grown on these fields (Cramer and Muhyi, 2002; Cramer et al., 2001, 2002). The high

Fig. 1. Individual onion bulbs from fall-sown onions in 2002 at Las Cruces, N.M., rated for fusarium basal rot severity from 1 to 9 (top left to bottom right).

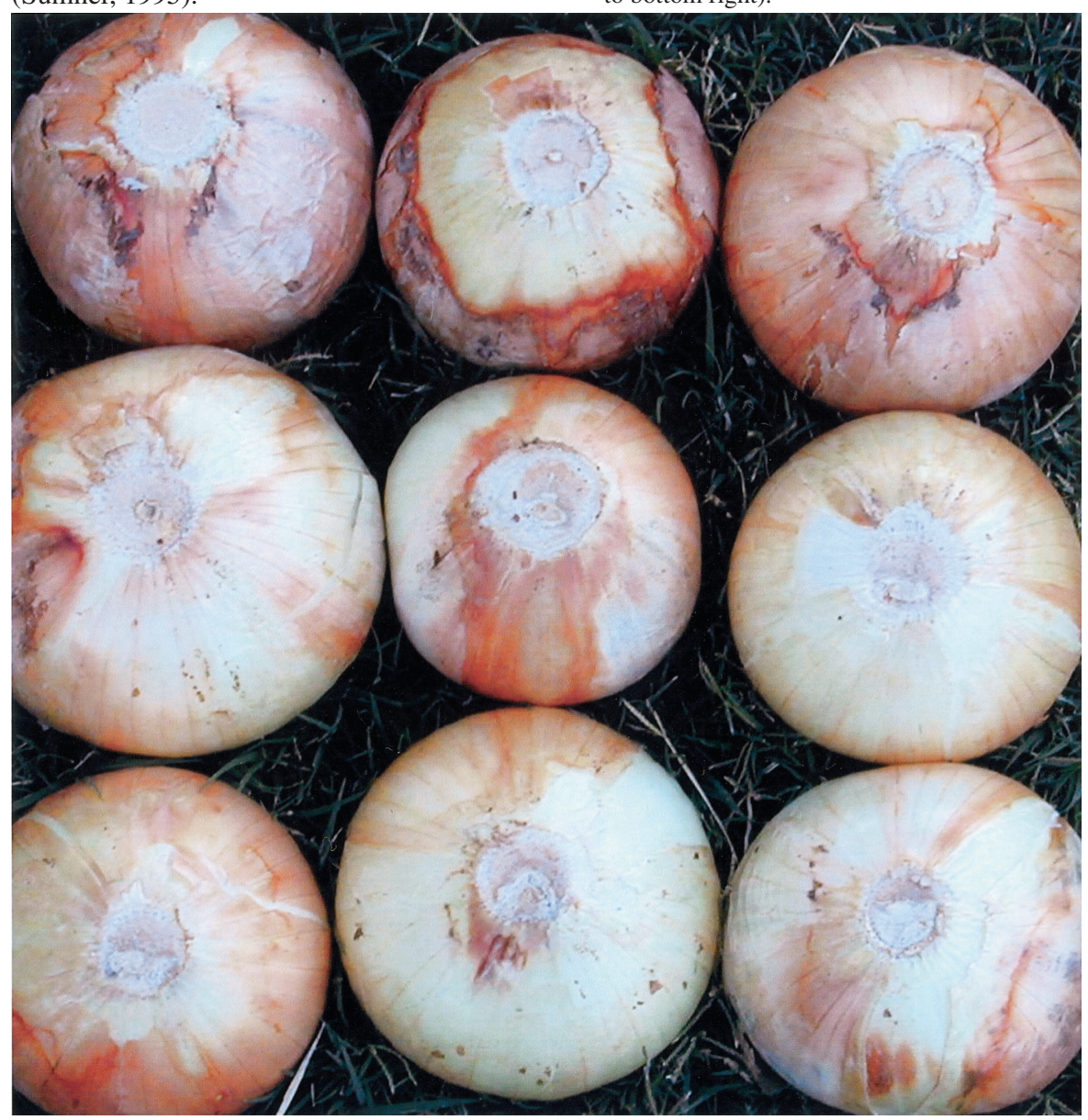


Table 1. Mean squares for fusarium basal rot (FBR) severity and incidence at harvest and 4 weeks after harvest for 26 onion cultivars at Las Cruces, N.M. in 2001 and 2002.

\begin{tabular}{|c|c|c|c|c|c|}
\hline \multirow[b]{2}{*}{ Source } & \multirow[b]{2}{*}{$\mathrm{df}$} & \multicolumn{2}{|c|}{ FBR severity } & \multicolumn{2}{|c|}{ FBR incidence } \\
\hline & & Harvest & 4 weeks & Harvest & 4 weeks \\
\hline Year & 1 & $8.5^{* * * *}$ & $3952.1^{* * *}$ & $24552.1^{* * * *}$ & $30811.1^{* * * *}$ \\
\hline Replication & 3 & $1.2^{* * *}$ & 14.1 & $1016.2^{* * *}$ & 166.7 \\
\hline Year $\times$ replication & 3 & $0.5^{*}$ & $160.8^{* * * *}$ & $1148.7^{* * * *}$ & $779.0^{* * *}$ \\
\hline Cultivar & 25 & $2.6^{* * *}$ & $125.0^{* * *}$ & $1719.3^{* * *}$ & $780.5^{* * *}$ \\
\hline Year $\times$ cultivar & 25 & $1.0^{* * * *}$ & $47.8^{* * *}$ & $609.0^{* * * *}$ & $339.4^{* *}$ \\
\hline Error & 149 & 0.2 & 11.9 & 107.8 & 160.6 \\
\hline Total & 206 & & & & \\
\hline
\end{tabular}

*,******* Significant at $P=0.05,0.01$, or 0.001 respectively. inoculum level is due to infected bulbs being incorporated into growing fields after each growing season, onions being successively planted in the same fields, and fungicides not being applied to control the disease. Entries were arranged in a randomized complete block Design with four replications per entry. Entries were seeded on 16 Sept. 2000 and 20 Sept. 2001 and were thinned on 25 Nov. 2000 and 31 Nov. 2001 to $10 \mathrm{~cm}$ in-row spacing. Each entry was seeded into beds formed $1 \mathrm{~m}$ center to center. Each plot was $2.4 \mathrm{~m}$ long with two rows spaced $20 \mathrm{~cm}$ between rows. Fields were managed using standard cultural practices for producing onions in southern New Mexico (Corgan et al., 2000). Preplant, $282.5 \mathrm{~kg} \cdot \mathrm{ha}^{-1}$ of triple superphosphate $(0.0 \mathrm{~N}-20.1 \mathrm{P}-0.0 \mathrm{~K})$ was applied. Subsurface drip irrigation tape placed $10 \mathrm{~cm}$ below the surface with $20 \mathrm{~cm}$ between emitters was used to apply water as needed. Uran 32 (urea and ammonium nitrate) $(32 \mathrm{~N}-0.0 \mathrm{P}-0.0 \mathrm{~K})$ was applied at 20 to 30 $\mathrm{mg} \cdot \mathrm{kg}^{-1}$ through drip lines for a total of 227 to $282 \mathrm{~kg} \cdot \mathrm{ha}^{-1}$ of nitrogen for the crop.

Bulb maturity was determined when about $80 \%$ of the tops within a plot had fallen over. Upon maturity, bulbs were harvested and the basal plates of 20 bulbs were cut transversely through the basal plate and rated for disease severity on a scale of $1=$ no diseased tissue to $9=70 \%$ or more diseased tissue) (Fig. 1). Mature bulbs were rated because they have been determined to be the most susceptible stage of plant development (Holz and Davies, 1974). In the 2002 season, knives were surface sterilized in a solution comprised of $20 \%$ bleach $(6 \% \mathrm{NaOCl})$ and $80 \%$ water, and dried between each cut, to avoid the spread of FOC from infected bulbs to noninfected bulbs. Twenty bulbs from each plot were used to calculate the mean disease severity for each entry. The average FBR incidence per plot was calculated from the percentage of sampled bulbs that showed any sign of infection by FOC for each entry.

Mature bulbs were evaluated to determine if the pathogen was present in asymptomatic basal plates at harvest. Before this study, FOC was isolated from symptomatic basal plate tissue and was confirmed as the causal agent (Lopez, 2003). After the initial rating was taken at harvest, the rating of each bulb was recorded on a paper bag in which the bulb was placed and stored at ambient conditions $\left(25\right.$ to $32{ }^{\circ} \mathrm{C}$ ) for 4 weeks. Bulbs were evaluated for FBR at 2 and 4 weeks after storage. These evaluation dates were chosen because in preliminary studies, disease symptoms were observed after storage for a short period of time. In addition, other researchers have delayed screening up to 5 months after harvest (Abawi and Lorbeer, 1971; Holz and Knox-Davies, 1974; Lorbeer and Stone, 1965; Marlatt, 1958; Retig et al., 1970; Stadnik and Dhingra, 1996). Bulbs that were rated with a score of nine at harvest were included for calculating severity and incidence at harvest but not stored for the progression study. Bulbs discarded for this reason were replaced with a new bulb that was rated, and stored. Bulbs from short-day onion cultivars have a short storage time before they break dormancy and start growing again. They normally remain dormant for only three months. As bulbs are stored for longer than 4 weeks, more bulbs are lost due to internal decay caused by bacterial diseases.

After 2 weeks in storage, FBR observations were taken, and bulbs were returned to storage for reevaluation at 4 weeks. A mean incidence for each cultivar was calculated from the average FBR incidence per plot. The means for each trait were calculated using the Means procedure of SAS statistical software (SAS Institute, Cary, N.C.). Within each group, differences between entries were calculated for each trait using the SAS general linear model procedure. Mean separation was determined with Fisher's least significant difference (LSD) test $(P=0.05)$.

\section{Results and Discussion}

For each of the traits measured, entries exhibited different responses depending upon the year tested (Table 1). A significant year by cultivar interaction was observed for each trait. For this reason, results for each year will be discussed by cultivar rather than averaged over years. The main difference between years was higher severity ratings and incidences in 2000 than in 2001 (Tables 2 and 3). There were a few instances in which a particular entry changed rank from one year to the next.

2001 Season. In the 2001 season, several entries had a low FBR severity and incidence at harvest with a few entries having a high severity and incidence. NMSU 00-13-1 had the lowest severity (1.1) and incidence $(13.8 \%)$ but was not significantly different from thirteen other entries in its severity and nine entries in its incidence (Table 2). In the past three years of NMSU variety trials, NMSU 00-13-1 and 'NuMex Starlite' also have exhibited low FBR severity and incidence (Cramer et al.,
Table 2. Fusarium basal rot (FBR) severity rating at harvest, and rating after 4 weeks of storage, and incidence at harvest, and after 4 weeks of storage for 26 fall-sown onion cultivars during 2001 at Las Cruces, N.M.

\begin{tabular}{|c|c|c|c|c|}
\hline Cultivar & $\begin{array}{l}\text { FBR severity } \\
\text { at harvest }{ }^{\mathrm{z}}\end{array}$ & $\begin{array}{c}\text { FBR severity at } \\
4 \text { weeks }^{y}\end{array}$ & $\begin{array}{l}\text { FBR incidence } \\
\text { at harvest }(\%)^{x}\end{array}$ & $\begin{array}{l}\text { FBR incidence at } \\
4 \text { weeks }(\%)^{\mathrm{w}}\end{array}$ \\
\hline$\overline{\text { Buffalo }}$ & 4.2 & 7.1 & 90.0 & 83.8 \\
\hline Cardinal & 4.8 & 6.6 & 92.5 & 85.0 \\
\hline Daybreak & 1.5 & 7.1 & 26.3 & 80.0 \\
\hline Don Victor & 1.6 & 6.4 & 30.0 & 68.8 \\
\hline Excalibur & 1.4 & 5.9 & 30.0 & 70.0 \\
\hline Ibex & 3.0 & 6.6 & 51.3 & 80.0 \\
\hline Nikita & 2.5 & 6.9 & 42.5 & 81.3 \\
\hline NMSU 98-17-1 & 2.4 & 5.2 & 48.8 & 68.8 \\
\hline NMSU 99-24 & 2.1 & 5.1 & 24.3 & 65.3 \\
\hline NMSU 99-28 & 2.3 & 3.4 & 68.8 & 47.5 \\
\hline NMSU 99-29-1 & 2.4 & 6.4 & 57.5 & 72.5 \\
\hline NMSU 00-12-1 & 1.6 & 4.9 & 40.0 & 56.3 \\
\hline NMSU 00-13-1 & 1.1 & 4.1 & 13.8 & 43.8 \\
\hline NMSU 00-25 & 1.3 & 3.2 & 23.8 & 35.0 \\
\hline NuMex BR1 & 1.5 & 4.9 & 28.3 & 65.0 \\
\hline NuMex Chaco & 1.7 & 4.9 & 48.8 & 68.8 \\
\hline NuMex Crispy & 2.1 & 5.0 & 57.5 & 73.8 \\
\hline NuMex Dulce & 2.2 & 4.9 & 36.3 & 57.5 \\
\hline NuMex Freedom & 1.3 & 4.1 & 15.0 & 55.0 \\
\hline NuMex Luna & 1.6 & 5.6 & 22.5 & 75.0 \\
\hline NuMex Mesa & 2.0 & 4.7 & 50.0 & 61.3 \\
\hline NuMex Starlite & 1.4 & 5.5 & 25.0 & 70.0 \\
\hline NuMex Sunlite & 1.2 & 4.3 & 17.5 & 58.8 \\
\hline NuMex Sweetpak & 1.8 & 4.6 & 50.0 & 52.5 \\
\hline NuMex Vado & 1.6 & 6.7 & 23.8 & 78.8 \\
\hline Texas Early White & 1.7 & 6.0 & 46.3 & 65.0 \\
\hline Mean & 2.0 & 5.4 & 37.3 & 66.1 \\
\hline LSD & $0.7^{* * *}$ & $1.3^{* * *}$ & $15.0^{* * * *}$ & $17.5^{* * *}$ \\
\hline
\end{tabular}

${ }^{\mathrm{z}}$ Cut basal plates of 20 bulbs per plot were rated based on a scale of 1 (no diseased tissue) to 9 (70\% or more of basal plate decayed).

${ }^{y}$ Basal plates of same 20 bulbs were recut and re-rated after 4 weeks in storage.

xPercentage of bulbs with fusarium basal plate rot.

"Percentage of same bulbs with fusarium basal plate rot after 4 weeks in storage.

**** Significant at $P=0.001$. 
2001, 2002; Cramer and Muhyi, 2002). In this study, 'Buffalo' and 'Cardinal' had significantly higher FBR severity and incidence compared to other entries. These two cultivars often exhibited the highest FBR severities and incidences of all cultivars in NMSU variety trials (Cramer et al., 2001, 2002; Cramer and Muhyi, 2002). 'Ibex', with a FBR disease severity of 3.0, was significantly better than 'Buffalo' or 'Cardinal' but was significantly worse than many other entries (Table 2). Although disease incidence and severity usually correlated well, NMSU 99-28 exhibited an unusually high disease incidence of $68.8 \%$, which was higher than all other entries except 'Buffalo' and 'Cardinal'.

In general, disease severity and incidence were proportional to each other for most entries, ie. low severity, low incidence; high severity, high incidence. However, several entries such as NMSU 00-12-1, 'NuMex Chaco', and 'Texas Early White' exhibited a low disease severity but moderate to high incidence. For example, 'NuMex Chaco' had a severity of 1.7 and an incidence of $48.8 \%$.

For most entries, disease severity and incidence increased during 4 weeks of storage. Numerous entries, including 'Buffalo' and 'Cardinal' exhibited high disease severity (Table 2). 'Daybreak', 'Don Victor', 'Excalibur', 'Ibex', 'Nikita', NMSU 99-29-1, 'NuMex Vado' and 'Texas Early White' had exhibited low disease severity at harvest time but after 4 weeks of storage were not different from 'Buffalo' and 'Cardinal' in disease severity. Bulbs of the mentioned entries were likely infected at harvest time but disease had not progressed very far. Given that development of FBR is often delayed until onions are stored, bulbs of breeding lines should be screened or rated after 4 weeks of storage in order to identify resistant bulbs properly. Even though disease severity increased with storage, NMSU 99-28, NMSU 00-13-1, NMSU 00-25, and 'NuMex Freedom' exhibited some of the lower severity ratings. These entries exhibit some level of FBR resistance and could be used in the development of short-day onion cultivars with FBR resistance. Other researchers also have observed an increase in FBR symptoms with storage or FBR disease development in healthy bulbs after storage (Marlatt, 1958; Retig et al., 1970; Stadnik and Dhingra, 1996). At harvest, determined that 13 short-day onion cultivars were moderately resistant to resistant to FBR. After 3 months of storage at $27^{\circ} \mathrm{C}$, only one cultivar was considered to be resistant while all other cultivars were moderately susceptible to susceptible.

In addition to disease severity, numerous entries exhibited a higher disease incidence after 4 weeks of storage (Table 2). For these entries, two-thirds or more of the bulbs were infected with FOC and various degrees of symptom expression were observed. Given time, disease likely would progress sufficiently to kill the entire basal plate in symptomatic bulbs. As mentioned previously, bulbs of the above entries must have been infected by harvest time but disease had not started or had not

Table 3. Fusarium basal rot (FBR) severity rating at harvest, and rating after 4 weeks of storage, and incidence at harvest, and after 4 weeks of storage for 26 fall-sown onion cultivars during 2002 at Las Cruces, N.M.

\begin{tabular}{|c|c|c|c|c|}
\hline Cultivar & $\begin{array}{l}\text { FBR severity } \\
\text { at harvest }\end{array}$ & $\begin{array}{c}\text { FBR severity at } \\
4 \text { weeks }^{y}\end{array}$ & $\begin{array}{l}\text { FBR incidence } \\
\text { at harvest }(\%)^{\mathrm{x}}\end{array}$ & $\begin{array}{c}\text { FBR incidence at } \\
4 \text { weeks }(\%)^{\mathrm{w}}\end{array}$ \\
\hline Cardinal & 2.1 & 3.8 & 45.0 & 56.3 \\
\hline Daybreak & 1.3 & 4.0 & 5.0 & 41.3 \\
\hline Don Victor & 1.5 & 5.4 & 14.0 & 57.2 \\
\hline Excalibur & 1.4 & 2.9 & 17.2 & 25.8 \\
\hline Ibex & 1.9 & 3.4 & 20.3 & 41.8 \\
\hline Nikita & 1.5 & 3.8 & 16.3 & 41.3 \\
\hline NMSU 98-17-1 & 2.6 & 3.6 & 45.0 & 40.0 \\
\hline NMSU 99-24 & 1.9 & 2.7 & 20.0 & 32.5 \\
\hline NMSU 99-28 & 1.2 & 4.0 & 10.0 & 47.5 \\
\hline NMSU 99-29-1 & 2.5 & 3.8 & 46.3 & 47.5 \\
\hline NMSU 00-12-1 & 1.5 & 2.8 & 11.3 & 26.3 \\
\hline NMSU 00-13-1 & 1.3 & 3.5 & 15.0 & 40.0 \\
\hline NMSU 00-25 & 1.3 & 2.2 & 18.8 & 22.5 \\
\hline NuMex BR1 & 1.3 & 3.7 & 5.0 & 38.8 \\
\hline NuMex Chaco & 1.4 & 3.5 & 17.5 & 38.8 \\
\hline NuMex Crispy & 1.2 & 3.1 & 7.5 & 35.0 \\
\hline NuMex Dulce & 1.8 & 3.8 & 22.5 & 55.0 \\
\hline NuMex Freedom & 1.4 & 2.8 & 11.3 & 38.8 \\
\hline NuMex Luna & 1.7 & 2.5 & 13.8 & 27.5 \\
\hline NuMex Mesa & 1.2 & 3.8 & 6.3 & 40.0 \\
\hline NuMex Starlite & 1.6 & 3.9 & 21.3 & 43.8 \\
\hline NuMex Sunlite & 1.4 & 4.0 & 16.3 & 43.8 \\
\hline NuMex Sweetpak & 1.5 & 2.6 & 13.8 & 31.3 \\
\hline NuMex Vado & 1.4 & 4.0 & 12.5 & 48.8 \\
\hline Texas Early White & 1.7 & 5.0 & 17.5 & 55.0 \\
\hline Mean & 1.6 & 3.6 & 18.9 & 41.7 \\
\hline $\operatorname{LSD}(5 \%)$ & $0.6^{* * * *}$ & $1.2^{* * *}$ & $14.3^{* * * *}$ & $18.2^{* * *}$ \\
\hline
\end{tabular}

${ }^{2}$ Cut basal plates of 20 bulbs per plot were rated based on a scale of 1 (no diseased tissue) to 9 (70\% or more of basal plate decayed).

${ }^{y}$ Basal plates of same 20 bulbs were recut and re-rated after 4 weeks in storage.

xercentage of bulbs with fusarium basal plate rot.

${ }^{\text {w}}$ Percentage of same bulbs with fusarium basal plate rot after 4 weeks in storage.

**** Significant at $P=0.001$.

progressed very far in those bulbs. However, after 4 weeks of storage, disease progressed further and was clearly visible.

2002 Season. FBR severity and incidence were much lower in the 2002 season than in the 2001 season (Table 3 ). The average disease severity and incidence was 1.6 and $18.9 \%$, respectively, in the 2002 season as compared to 2.0 and $37.3 \%$, respectively in the 2001 season. From variety trials conducted in the same years at the same location, entries generally matured earlier in the 2002 season than in the 2001 season (Cramer et al., 2002; Cramer and Muhyi, 2002). In addition, many of the entries tested in this study and in the variety trials exhibited a lower disease incidence in the 2002 season than in the 2001 season when tested in variety trials (Cramer et al., 2002; Cramer and Muhyi, 2002).

At harvest time, many entries exhibited a low disease severity and incidence (Table 3). These entries included some of the same entries that exhibited low severity in the first year such as 'Daybreak', NMSU 00-13-1, NMSU 00-25, 'NuMex BR1', 'NuMex Freedom', 'NuMex Luna', 'NuMex Sunlite', and 'NuMex Vado'. In addition to those entries, numerous other entries exhibited a low disease severity and incidence at harvest time. 'Buffalo', 'Cardinal', NMSU 98-17-1, and NMSU 99-29-1 exhibited the highest disease severities and incidences. In the previous year, 'Buffalo' and 'Cardinal' also had exhibited the highest disease severities and incidences.

As observed in the first year, disease severity and incidence in the second year also increased as bulbs were stored for 4 weeks (Table 3). After 4 weeks of storage, the average disease severity and incidence were 3.6 and $41.7 \%$, respectively, as compared to 1.6 and $18.9 \%$, respectively, at harvest time. 'Excalibur', NMSU 99-24, NMSU 00-12-1, NMSU 00-25, 'NuMex Crispy', 'NuMex Freedom', 'NuMex Luna', and 'NuMex Sweetpak' exhibited the lowest disease severities and incidences. Of those entries, only NMSU 99-24 did not exhibit a low disease severity and incidence at harvest time. In the first year, NMSU 00-25 also exhibited the lowest severity and incidence after 4 weeks of storage.

After 4 weeks of storage, bulbs of 'Buffalo', 'Don Victor', and 'Texas Early White' exhibited the highest disease severities and incidences of the entries tested (Table 3). 'Cardinal' and 'NuMex Dulce' also exhibited a high disease incidence after bulbs were stored. In the previous year, 'Buffalo' and 'Don Victor' also exhibited a high disease severity and incidence after 4 weeks of storage. Also in the first year, 'Texas Early White' had exhibited a high disease severity and 'Cardinal' had exhibited a high disease incidence after storage. 'Don Victor' and 'Texas Early White' exhibited low values for severity and incidence at harvest and high values after storage. In addition, 'Daybreak', Nikita', NMSU 99-28, NMSU 00-13-1, 'NuMex Sunlite', and 'NuMex Vado' exhibited the lowest severities and incidences at harvest but were no longer in the lowest group after bulb storage for 4 weeks.

In conclusion, entries should be evaluated 
across years for fusarium basal rot resistance. Disease severity and incidence can vary greatly from year to year. These yearly differences make breeding for resistance difficult to achieve. In addition, bulbs should be stored for a length of time to allow for disease development. Disease severity and incidence continues to increase after bulbs are stored. This would ensure a proper evaluation of FBR resistance and help in the development of resistant cultivars. Of the entries tested, NMSU 00-25 exhibited the lowest disease severity and incidence in both years. This entry would be a logical choice to use for the development of FBR resistant cultivars. Both 'Buffalo' and 'Cardinal' can serve as FBR susceptible controls in the development of resistant cultivars.

\section{Literature Cited}

Abawi, G.S. and J.W. Lorbeer. 1971. Reaction of selected onion varieties to infection by $\mathrm{Fu}$ - sarium oxysporum f. sp. cepae. Plant Dis. Rptr. 55:1000-1004.

Abawi, G.S. and J.W. Lorbeer. 1972. Several aspects of the ecology and pathology of $\mathrm{Fu}$ sarium oxysporum $\mathrm{f}$. sp. cepae. Phytopathology 62:870-876.

Bacher, J.W., S. Pan, and L. Ewart. 1989. Inheritance of resistance to Fusarium oxysporum $\mathrm{f}$. sp cepae in cultivated onions, p. 85-91. In: L. Jensen (ed.). Proc. 1989 Natl. Onion Res. Conf., Boise, Idaho.

Corgan, J.N., M.M. Wall, C.S. Cramer, T. Sammis, B. Lewis, and J. Schroeder. 2000. Bulb onion culture and management. N.M. Coop. Ext. Serv. Circ. 563.

Cramer, C.S., J.L. Mendoza, and M.M. Wall. 2001 1999-2000 onion variety trials at New Mexico State University. N.M. Agr. Expt. Sta. Res. Rpt. 38.

Cramer, C.S., J.L. Mendoza, and M.M Wall. 2002. 2000-2001 onion variety trials at New Mexico State University. N.M. Agr. Expt. Sta. Res. Rpt. 748.

Cramer, C.S. and R.I. Muhyi. 2002. 2001-2002 Fall planted onion variety trials at New Mexico State
University, p. 23-33. In: G. Pelter (ed.). Proc. 2002 Natl. Onion Res. Conf., Pasco, Wash.

Holz, G. and P.S. Knox-Davies. 1974. Resistance of onion selections to Fusarium oxysporum f. sp. cepae. Phytophylactica 6:153-156.

Lorbeer, J.W. and K.W. Stone. 1965. Reaction of onion to Fusarium basal rot. Plant Dis. Rptr. 49:522-526.

Lopez, J.A. 2003. Screening onion cultivars for resistance to fusarium basal rot. MS thesis. N.M. State Univ., Las Cruces.

Marlatt, R.B. 1958. Onion Fusarium basal rot in Arizona. Plant Dis. Rptr. 42:667-668.

Retig, N., A.F. Kust, and W.H. Gabelman. 1970. Greenhouse and field tests for determining the resistance of onion lines to Fusarium basal rot. J. Amer. Soc. Hort. Sci. 95:422-424.

Stadnik, M.J. and O.D. Dhingra. 1996. Response of onion genotypes to Fusarium oxysporum f. sp. cepae during the growth phase and in storage. Fitopatol. Bras. 21:431-435.

Sumner, D.R. 1995. Fusarium basal plate rot, p. 10-11. In: H.F. Schwartz and S.K. Mohan (eds.). Compendium of onion and garlic diseases.Amer. Phytopathol. Soc., St. Paul, Minn. 